\title{
A Proposal To Transfer Microbispora bispora (Lechevalier 1965) to a New Genus, Thermobispora gen. nov., as Thermobispora bispora comb. nov.
}

\author{
YUE WANG, ${ }^{*}$ ZHENSHUI ZHANG, AND JISHENG RUAN \\ Microbial Collection and Screen Laboratory, Institute of Molecular and Cell Biology, \\ National University of Singapore, Singapore 119260
}

\begin{abstract}
We determined almost complete 16S rRNA gene sequences of two Microbispora bispora (Lechevalier 1965) strains, ATCC 19993 ${ }^{\mathrm{T}}(\mathrm{T}=$ type strain) and JCM 3082. The two sequences were $99 \%$ similar to each other but exhibited only 81 to $87.8 \%$ similarity with the 16S rRNA gene sequences of seven other Microbispora strains. A phylogenetic analysis revealed that the two sequences clustered not only distantly from other Microbispora strains, but also outside the cluster containing members of the family Streptosporangiaceae. On the basis of the results of our phylogenetic analysis and the results of a comprehensive review of the genus Microbispora by Miyadoh et al. (S. Miyadoh, S. Amano, H. Tohyama, and T. Shomura, J. Gen. Microbiol. 136:1905-1913, 1990) in which chemotaxonomic and DNA-DNA hybridization analyses were performed, we propose that Microbispora bispora should be transferred to a new genus, Thermobispora gen. nov., as Thermobispora bispora comb. nov.
\end{abstract}

The genus Microbispora was proposed by Nonomura and Ohara (14) in 1957 for actinomycetes that form conspicuous aerial mycelia bearing longitudinal pairs of spores. This genus contains 11 validly described species, and Microbispora rosea is the type species (9, 10, 13-15). In 1990 Miyadoh et al. (12) conducted a comprehensive taxonomic review of the genus Microbispora by using chemotaxonomic and DNA-DNA hybridization techniques. On the basis of a mean DNA homology value of 56.6\%, 10 Microbispora species were combined into one species, Microbispora rosea. Microbispora bispora (Lechevalier 1965) (9), which was originally described by Henssen as Thermopolyspora bispora (4), remained separate species mainly because of its low levels of DNA-DNA homology (mean, $16.4 \%$ ) with the 10 other species.

There is evidence that Microbispora bispora strains differ in many ways from the other 10 Microbispora species. Some of the differences seem greater than the differences usually observed between different species belonging to the same genus. In addition to its low levels of DNA homology with the other Microbispora species, Microbispora bispora can also be distinguished on the basis of its growth temperature, its predominant menaquinone species, its phospholipid species, its major fatty acid species, and the electrophoretic pattern of its ribosomal proteins $(12,16)$. Microbispora bispora grows at $65^{\circ} \mathrm{C}$ but not at $35^{\circ} \mathrm{C}$ or lower temperatures. The 10 other Microbispora species can be divided into two groups, a mesophilic group and a thermophilic group, on the basis of their growth temperature ranges, but none of them can grow at temperatures above $60^{\circ} \mathrm{C}$ $(4,12)$. Microbispora bispora strains contain small amounts of glucosamine-containing phospholipids, and $\mathrm{MK}-9\left(\mathrm{H}_{0}\right)$ is the predominant menoquinone of this organism, while the 10 other Microbispora species contain large amounts of glucosamine-containing phospholipids and MK-9 $\left(\mathrm{H}_{4}\right)$, MK$9\left(\mathrm{H}_{2}\right)$, and MK- $9\left(\mathrm{H}_{0}\right)$ are the predominant menoquinones (12). Ochi et al. reported that Microbispora bispora ATCC $19993^{\mathrm{T}}(\mathrm{T}=$ type strain) produced a ribosomal protein pattern

\footnotetext{
* Corresponding author. Mailing address: Institute of Molecular and Cell Biology, National University of Singapore, 10 Kent Ridge Crescent, Singapore 119260. Phone: 65 7783207. Fax: 657791117. Electronic mail address: mcbwangy@leonis.nus.sg.
}

on a two-dimensional polyacrylamide gel electrophoresis (PAGE) analysis gel that was very different from the patterns produced by other Microbispora strains (16). Furthermore, Microbispora bispora, Microtetrapsora pusilla, and Microtetraspora ferruginea were found to have comparable levels of DNA-DNA homology with the 10 other Microbispora species (12).

16S rRNA gene sequence-based phylogenetic analysis has proven to be a powerful tool for determining relationships between organisms that more conventional methods have problems defining $(18,21-23)$. In the present study, we determined the $16 \mathrm{~S}$ rRNA gene sequences of two Microbispora bispora strains (strains ATCC $19993^{\mathrm{T}}$ and JCM 3082) and analyzed the phylogenetic relationships between these strains and other species or strains belonging to the genus Microbispora and members of other actinomycete groups.

\section{MATERIALS AND METHODS}

Organisms and culture conditions. Microbispora bispora JCM 3082, Kutzneria viridogrisea JCM $3282^{\mathrm{T}}$, and Actinomadura madurae $\mathrm{JCM} 7436^{\mathrm{T}}$ were purchased from the Japan Collection of Microorganisms, Wako, Japan. Microbispora bispora ATCC $19993^{\mathrm{T}}$ and ATCC 15737, Actinoplanes philippinensis ATCC $12427^{\mathrm{T}}$, Dactylosporangium aurantiacum ATCC $23491^{\mathrm{T}}$, Micromonospora chalcea ATCC 12452, and Micromonospora echinospora subsp. echinospora ATCC $15837^{\mathrm{T}}$ were obtained from the American Type Culture Collection, Rockville, Md. Actinoplanes auranticolor IFO $12245^{\mathrm{T}}$, Microbispora bispora IFO $14880^{\mathrm{T}}$, and Dactylosporangium roseum IFO $14352^{\mathrm{T}}$ were obtained from the Institute for Fermentation, Osaka, Japan. Microbispora bispora DSM 43038 was obtained from DSM-German Collection of Microorganisms and Cell Cultures. The organisms were cultured in the media and conditions described by the suppliers.

Culture observations and morphological characterization. Microbispora bispora ATCC $19993^{\mathrm{T}}$ and JCM 3082 were inoculated onto International Streptomyces Project medium 4 agar, Bennett's agar, and IFO328 agar (Institute for Fermentation). After inoculation, sterilized glass coverslips were inserted in the agar media. The plates were incubated at 28,37 , and $60^{\circ} \mathrm{C}$ for 14 days. The coverslips were stained and examined with a light microscope (model DM RB; Leitz).

Preparation of genomic DNA. Mycelia of actinomycete strains were harvested by centrifugation at $3,600 \times g$ for $5 \mathrm{~min}$ in a model $5410 \mathrm{C}$ microcentrifuge (Eppendorf, Hamburg, Germany). Approximately $200 \mu \mathrm{l}$ of wet mycelia was transferred to a $1.5-\mathrm{ml}$ Eppendorf microcentrifuge tube. The mycelia were resuspended in $500 \mu \mathrm{l}$ of lysozyme buffer containing $25 \mathrm{mM}$ Tris-Cl (pH 8.0), 50 $\mathrm{mM}$ glucose, $10 \mathrm{mM}$ EDTA, and $5 \mathrm{mg}$ of lysozyme (Sigma Chemical Co., St. Louis, Mo.) per $\mathrm{ml}$ and incubated at $37^{\circ} \mathrm{C}$ for $30 \mathrm{~min}$. After lysozyme digestion, sodium dodecyl sulfate was added to a final concentration of $1 \%$, and each tube was incubated at $65^{\circ} \mathrm{C}$ for $30 \mathrm{~min}$. Each cell lysate was extracted twice with an equal volume of phenol and once with chloroform-isoamyl alcohol $(24: 1)$. The nucleic acid was precipitated with 1 volume of isopropanol at room temperature until a thread-like precipitate appeared. Then the nucleic acid preparation was 
centrifuged in an Eppendorf microcentrifuge at $14,000 \times g$ for $5 \mathrm{~min}$. The supernatant was decanted, and the tube was left inverted on a piece of paper towel for $10 \mathrm{~min}$. The nucleic acid was resuspended in $100 \mu \mathrm{l}$ of $10 \mathrm{mM}$ Tris-1 mM EDTA ( $\mathrm{pH} 7.5$ ) containing $100 \mu \mathrm{g}$ of DNase-free RNase A (Sigmal Chemical $\mathrm{Co}$.) per $\mathrm{ml}$ and incubated at $37^{\circ} \mathrm{C}$ for $30 \mathrm{~min}$. The nucleic acid was extracted once with phenol-chloroform (1:1), precipitated, and resuspended as described above.

Oligonucleotides used for PCR and sequencing. The two primers used for PCR amplification of nearly complete $16 \mathrm{~S}$ rRNA genes were 5'TTACCTGAT AGCGGCCGCAGAGTTTGATCCTGGCTCAG3' (nucleotides 8 to 27 of the Escherichia coli 16S rRNA gene) (1) and 5'TACAGGATCCGCGGCCGCTAC GG(C/T)TACCTTGTTACGACTT3' (nucleotides 1492 to 1513) (the underlined sequences are cleavage sites of restriction enzyme Not I). The nonspecific nucleotides on the $5^{\prime}$ side of the Not I site were included for efficient cleavage by Not $\mathrm{I}$. The ends of cloned $16 \mathrm{~S}$ ribosomal DNAs were sequenced by using the M13 forward sequencing primer 5'GTTTTCCCAGTCACGAC3' and reverse primer 5 'GCGGATAACAATTTCACACAGG3'. The internal regions were sequenced in both orientations by using the following cight oligonucleotide primers whose target sequences were obtained either from previous reports (8) or from an alignment of the 16S rRNA genc sequences of many actinomycete species: 5'GCCTATCAGCTTGTTGGT3' (nucleotides 239 to 256), 5' CGTGCCAGCA 'GCCGCGGT3' (nucleotides 514 to 531), 5'TAGATACCCTGGTAGTCC3' (nucleotides 789 to 806), 5'CCGCAACGAGCGCAACCC3' (nucleotides 1097 to 1114), 5'TACCGCGGC(G/T)GCTGGCAC3' (nucleotides 532 to 515 ), 5'G GACTACC(A/C/G)GGGTATCTAAT3' (nucleotides 806 to 787), 5'GGGTTG CGCTCGTTGCGG3' (nucleotides 1114 to 1097), and 5'ACGGGCGGTGTG TAC (nucleotides 1406 to 1392). All of the oligonucleotides were synthesized by Oligos Etc., Inc., Wilsonville, Oreg.

PCR amplification of 16S rRNA genes. Each PCR mixture contained $100 \mathrm{ng}$ of genomic DNA, 20 pmol of each of the two universal primers, $200 \mu \mathrm{M}$ dATP, 200 $\mu \mathrm{M}$ dGTP, $200 \mu \mathrm{M}$ dCTP, $200 \mu \mathrm{M}$ dTTP, $2.5 \mathrm{U}$ of Taq DNA polymerase (Amersham, Aylesbury, Buckinghamshire, England), and $1 \times$ buffer (the buffer provided with Taq DNA polymerase); the final volume was $100 \mu \mathrm{l}$. The PCR program used was 25 cycles consisting of $95^{\circ} \mathrm{C}$ for $40 \mathrm{~s}, 52^{\circ} \mathrm{C}$ for $30 \mathrm{~s}$, and $72^{\circ} \mathrm{C}$ for $2 \mathrm{~min}$. The PCR products were purified with a QIAquick Spin PCR purification kit (QIAGEN GmbH, Hilden, Germany) and were quantified by using the BRL GIBCO FastCheck nucleic acid quantification system (GIBCO BRL Life Technologies, Gaithsburg, Md.)

Cloning and sequencing of 16S ribosomal DNA. The purified PCR products of 16S rRNA genes were cut with NotI (Amersham) and cloned into plasmid Bluescript SK (Stratagene, La Jolla, Calif.). E. coli DH5 $\alpha F^{\prime}$ cells (GIBCO BRL) were prepared and transformed as described previously (11). Recombinant clones were picked and grown in $2 \mathrm{ml}$ of Luria-Bertani (11) medium overnight, and the recombinant plasmid DNA was prepared by using a miniplasmid preparation kit (QIAGEN, Germany). Each cloned 16S ribosomal DNA was manually sequenced in both orientations by using an Amersham Sequenase kit (version 2.1).

Sequence alignment and phylogenetic analysis. Multiple alignments of sequences and calculations of levels of sequence similarity were carried out by using the Clustal method of the DNASTAR program (DNASTAR, Inc., Madison, Wis.). Phylogenetic trees were constructed by using the maximum-parsimony method contained in the PAUP package (19). The sequences were added randomly to circumvent the problem of entrapment in local optima. The confidence lcvel of the phylogenetic tree topology was evaluated by performing 100 bootstrap replications with the BOOTSTRAP program contained in the same package.

Nucleotide sequence accession numbers. The 16S rRNA gene sequences determined in this study have been deposited in the GenBank database under the following accession numbers: Microbispora bispora JCM 3082, U58524; Micro bispora bispora ATCC $19993^{\mathrm{T}}$, U58523; Actinoplanes philippinensis, U58525; Actinoplanes auranticolor, U58526; Actinomadura madurae, U58527; Dactylosporangium aurantiacum, U58528; Dactylosporangium roseum, U58529; Kutzneria viridogrisea, U58530; Micromonospora chalcea, U58531; and Micromonospora echinospora subsp. echinospora, U58532.

The GenBank accession numbers of 16S rRNA gene sequences that we reported previously (20) are as follows: Actinomadura atramentaria, U49000; Actinomadura citrea, U49001; Actinomadura coenulea, U49002; Actinomadura cremea subsp. rifamycini, U49003; Actinomadura echinospora, U49004 Actinomadura fulvescens, U49005; Actinomadura kijaniata, U49006; Actinomadura libanotica, U49007; Actinomadura luteofluorescens, U49008; Actinomadura macra, U49009; Actinomadura nugatobispora, U49010; Actinomadura verrucosospora, U49011; Microbispora aerata, U48984; Microbispora amethystogenes, U48988; Microbispora chromogenes, U48989; Microbispora diastatica, U48990 Microbispora parva, U48985; Microbispora thermodiastatica, U14986; Microbispora thermorosea, U48987; Microtetraspora africana, U48842; Microtetraspora angiospora, U48843; Microtetraspora fastidiosa, U48844; Microtetraspora ferm ginea, U48845; Microtetraspora fusca, U48973; Microtetraspora glauca, U48974 Microtetraspora helvata, U48975; Microtetraspora niveoalba, U48976; Microtetraspora polychroma, U48977; Microtetraspora pusilla, U48978; Microtetraspora recticatena, U48979; Microtetraspora roseola, U48980; Microtetraspora salmonea U48982; Microtetraspora spiralis, U48983; Streptosporangium corrugatum, U48991; Streptosporangium fragile, U48992; Streptosporangium longisporum,
U48993; Streptosporangium nondiastaticum, U48994; Streptosporangium pseudovulgare, U48995; Streptosporangium roseum, U48996; Streptosporangium violaceochromogenes, U48997; Streptosporangium viridialbum, U48998; and Streptosporangium vulgare, U48999.

The sequences of the following organisms were retrieved from public databases: Actinosynnema minum (EMBL accession number X84447), Bifidobacterium bifidum (GenBank accession number U25952), Geodermatophilus obscurus (EMBL accession number L40620), Kibdelosporangium aridum (EMBL accession number M29283), Nocardia asteroides (EMBL accession number X57949), Nocardia seriolae (EMBL accession number X36925), Promicromonospora enterophila (EMBL accession number X83807), Saccharothrix coeruleofusca (EMBL accession number X76963), Saccharothrix mutabilis (EMBL accession number X76965), Saccharopolyspora erythraea (EMBL accession number X53198), Saccharopolyspora hirsuta (EMBL accession number X53196), Saccharomonospora caesia (EMBL accession number Z38024), Saccharomonospora viridis (EMBL accession number Z38007), Streptomyces coelicolor (EMBL accession number Y00411), Streptomyces galbus (EMBL accession number X79852), Tsukamurella inchonenesis (EMBL accession number X85955), and Tsukamurella paurometabola (EMBL accession number Z36933).

\section{RESULTS AND DISCUSSION}

Cultural and morphological features. The cultural and morphological features of Microbispora bispora strains are generally the same as those described previously $(4,9)$. These bacteria are gram-positive organisms which form substrate mycelia whose hyphae are 0.5 to $0.8 \mu \mathrm{m}$ in diameter and aerial mycelia that branch monopodially and bear longitudinal pairs of spores. The spore diameters are usually 1.2 to $2.0 \mu \mathrm{m}$, but in liquid media spores with a diameter of $3 \mu \mathrm{m}$ have been observed. The aerial mycelia are white, and the substrate mycelia are yellow or yellowish brown on the media which we used. No soluble pigment is produced.

Comparative 16S rRNA gene sequence analysis. We determined almost complete 16S rRNA gene sequences (nucleotides 3 to 1491 [E. coli numbering] [1]) for two Microbispora bispora strains, strains JCM 3082 and ATCC $19993^{\mathrm{T}}$. We also determined the 16S rRNA gene sequences of Microbispora bispora ATCC 15737, DSM 43038 (equivalent to JCM 3082), and IFO 14880 (equivalent to ATCC $19993^{\mathrm{T}}$ ) in order to confirm the reliability of our sequence results. A pairwise sequence similarity analysis revealed that these five sequences were 99 to $99.8 \%$ similar. In the analysis described below only the sequences of two strains, strains ATCC $19993^{\mathrm{T}}$ and JCM 3082, were included (these sequences have been deposited in the GenBank database). Table 1 shows that the sequences of strains ATCC $19993^{\mathrm{T}}$ and JCM 3082 are $99 \%$ similar to each other, but only 81 to $87.8 \%$ similar to the $16 \mathrm{~S}$ rRNA gene sequences of other Microbispora strains (belonging to 7 of the 10 Microbispora species combined in the taxon Microbispora rosea by Miyadoh et al. [12]), which are 95.8 to $99.2 \%$ similar to each other. Microbispora bispora also exhibits low levels of sequence similarity (about $81 \%$ ) to Microtetrasporsa glauca and Streptosporangium roseum, the type species of two other genera in the family Streptosporangiaceae (3); in contrast, the average levels of similarity between the latter two species and the seven other Microbispora strains studied are 95 and $91 \%$, respectively. We noticed that the levels of similarity between the sequence of Microbispora bispora and the sequences of $\mathrm{Mi}$ crotetraspora glauca and Streptosporangium roseum (about $81 \%$ ) are much lower than the intergeneric levels of similarity in the family Streptosporangiaceae, which range from 90 to $96 \%$ (20). The $81 \%$ value is even lower than the levels of similarity between the Actinomadura species of the Thermomonosporaceae and members of the Streptosporangiaceae (>88\%) (20). These observations demonstrate that Microbispora bispora is only distantly related to other Microbispora strains and other members of the family Streptosporangiaceae.

To determine the phylogenetic affiliation between Microbispora bispora and members of the family Streptosporangi- 


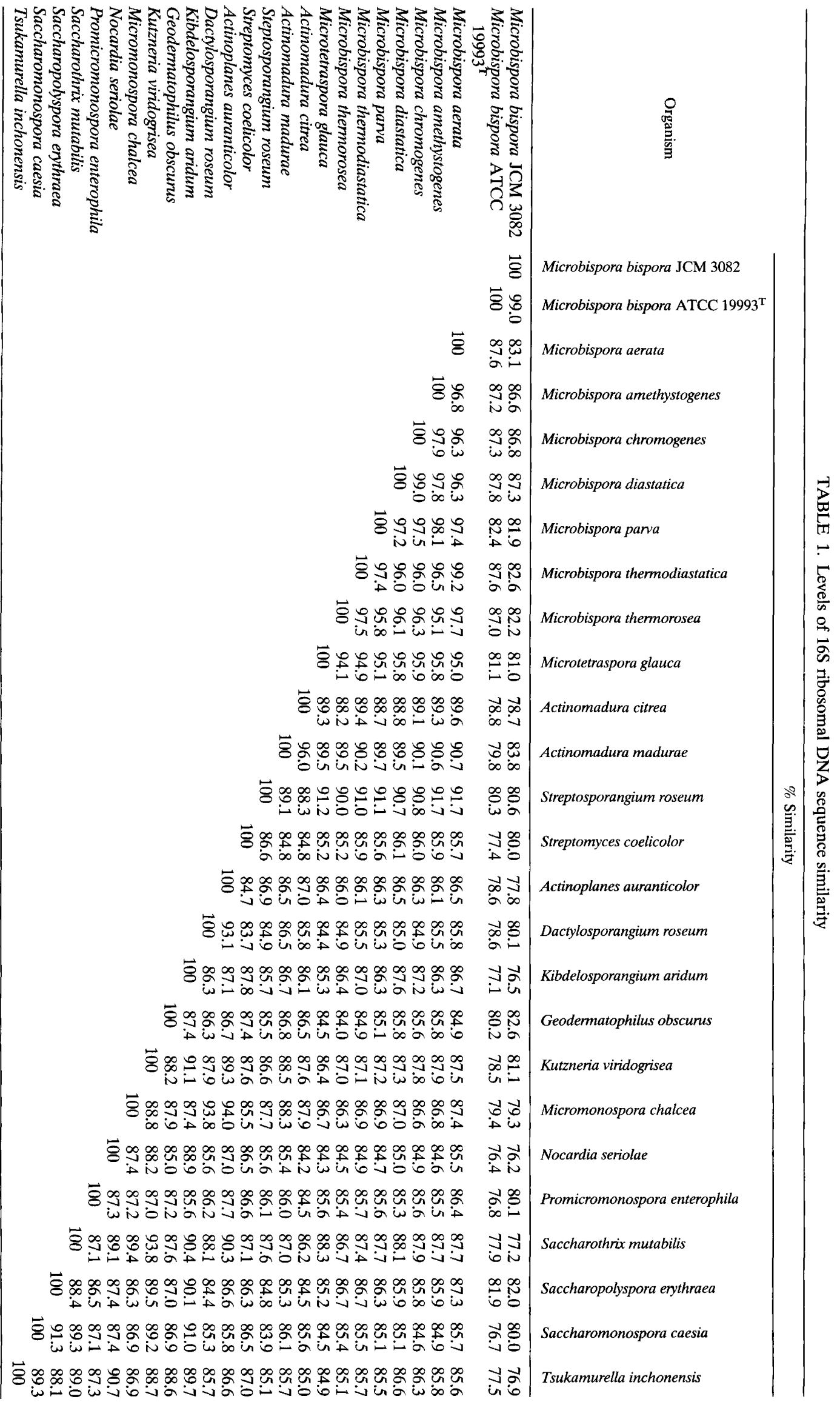




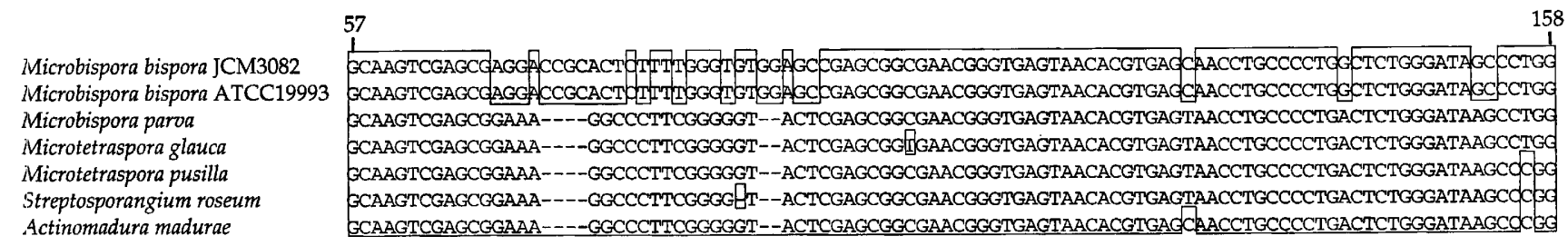

Microbispora bispora JCM3082 Microbispora bispora ATCC19993 Microbispora parva GAAACCGGGTCTAATACCGGATATGACACT-CCTCEGCATGGTGTGQGT-GTGGAAAGTTT---------TTTCGGTTGGGGATGGGCTCGCGGCCTA GAAACTGGGTCTAATACCGGATATGACCAC-TTDGGGCATCCAATGGTG-GTGGAAAGTTT---2-..---TTTCGGTTGGGGATGGACTCGCGGCCTA GAAACTGGGTCTAATACCGGATACGACCAC-TDdAGGCATCTJGTGGTG-GTGGAAAGAAd--------TTTEGGTCAGGGATGGGCTCGCGGCCTA

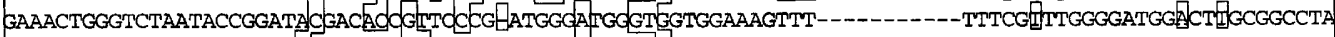
GAAACTGGGTCTAATACCGGATGIGACCGCACLCTCGCATGGOATGGTGTGTGGAAAGTTT----------TTTCGGTTGGGGATGGGCTCGCGGCCTA

FIG. 1. Alignment of 16S rRNA gene sequences. The 16S rRNA gene sequences of two Microbispora bispora strains were aligned with the sequences of members of other genera of the family Streptosporangiaceae. The nucleotide sequence of Actinomadura madurae $16 \mathrm{~S}$ rRNA gene was also included. The region corresponding to $E$. coli nucleotide positions 57 to $243(1)$ is shown. The nucleotides that differ from other nucleotides at the same position are enclosed in boxes. The multisequence alignment was prepared by using the MEGALIGN program of DNASTAR.

aceae, the sequence of Microbispora bispora was analyzed together with the sequences of 14 Microtetraspora species, 7 Microbispora strains, and 8 Streptosporangium species by using Swofford's PAUP (phylogenetic analysis using parsimony) program (19). The sequences of 12 Actinomadura species were also included in the analysis because of the historical taxonomic association of these organisms with members of the Streptosporangiaceae $(2,3,7)$. All of the sequences could be aligned without generating significant ambiguity, except that the two Microbispora bispora sequences contained some nucleotides which were not present in the other sequences, including the sequences of the seven other Microbispora strains. Figure 1 shows the region corresponding to nucleotides 57 to 243 of the E. coli $16 \mathrm{~S}$ rRNA gene (1). The sequences of the Microbispora bispora strains had a stretch of 11 nucleotides around position 210 which seemed to be unique to this species because it was not found in any other actinomycete $16 \mathrm{~S}$ rRNA genes retrieved from the public databases. Extra nucleotides were also observed in the region around nucleotide 80 , and these nucleotides were not present in the sequences of the other members of the Streptosporangiaceae. These nucleotide signatures could serve as markers for identification of Microbispora bispora strains. Inclusion or exclusion of these nucleotides in the phylogenetic analysis had no effect on the topology of the most parsimony tree shown in Fig. $2 \mathrm{a}$. As we have reported elsewhere $(20)$, the seven strains of Microbispora rosea formed a major cluster with the members of the genera Microtetraspora and Streptosporangium, and all of the Actinomadura species formed a second major cluster; the stabilities of these two major clusters were supported by 99 and 100 bootstrap values, respectively. The two Microbispora bispora strains were located some distance outside the two major clusters representing the lamilies Streptosporangiaceae and Thermomonosporaceae (3, 7). To determine the possible affiliation of Microbispora bispora with other groups of actinomycetes, we compared the Microbispora bispora sequences with the sequences of 39 representative species belonging to 19 genera in a phylogenetic analysis. The phylogenetic tree which we obtained is shown in Fig. $2 b$. Again, Microbispora bispora was located outside the clusters containing Actinomadura species and the members of the Streptosporangiaceae. However, the Microbispora bispora strains appeared to be most closely related to the members of the latter two groups, forming a cluster of a higher order with a significant bootstrap value (94). The results of the sequence similarity and phylogenetic analyses described above demonstrate that Microbispora bispora does not belong to the genus Microbispora and very likely does not even belong to the family Streptosporangiaceae.

The phylogenetic separation of Microbispora bispora from the genus Microbispora may gain strong support from several distinctive properties of this organism. The absolutely thermophilic lifestyle of Microbispora bispora can be distinguished from the mesophilic and facultatively thermophilic (growth at both 35 and $55^{\circ} \mathrm{C}$ ) lifestyles of the other Microbispora strains. It is reasonable to conclude that organisms that grow at temperatures as high as $65^{\circ} \mathrm{C}$ need proteins with very different thermostabilities than the thermostabilities of the proteins of organisms that grow at temperatures which are 10 to $30^{\circ} \mathrm{C}$ lower. This hypothesis is supported by the very different ribosomal protein pattern of Microbispora bispora revealed by a twodimensional PAGE analysis (16) and by the low levels of DNADNA association with other Microbispora strains (12). Microbispora bispora can also be distinguished by chemotaxonomic properties. This organism contains $\mathrm{MK}-9\left(\mathrm{H}_{0}\right)$ as the predominant menaquinone; in contrast, the predominant menaquinones found in other Microbispora strains are $\mathrm{MK}-9\left(\mathrm{H}_{4}\right)$, MK$9\left(\mathrm{H}_{2}\right)$, and MK-9 $\left(\mathrm{H}_{0}\right)(12)$. Microbispora bispora also contains much lower amounts of glucosamine-containing phospholipid and 10-methyl fatty acid than other Microbispora strains (12).

Proposal to transfer Microbispora bispora to a new genus. On the basis of phylogenetic, chemotaxonomic, and DNA-DNA hybridization evidence and growth temperature data, we propose that Microbispora bispora (Lechevalier 1965) should be transferred to a new genus, Thermobispora gen. nov. The genus name refers to the thermophilic lifestyle of the organism and to the formation of pairs of spores on aerial hyphae. The type species is Thermobispora bispora comb. nov. However, the taxonomic position of the genus Thermobispora within the order Actinomycetales cannot be determined because the 16S rRNA gene sequences of members of many actinomycete genera are not available for comparison.

The taxonomic status of the 10 Microbispora strains combined by Miyadoh et al. as Microbispora rosea (12) on the basis of DNA-DNA association values needs to be reviewed. Obviously, when Thermobispora bispora was used as a reference, the levels of DNA-DNA relatedness among the 10 other species appeared to be higher. The new taxonomic position of Thermobispora bispora also explains the comparable levels of DNA- 

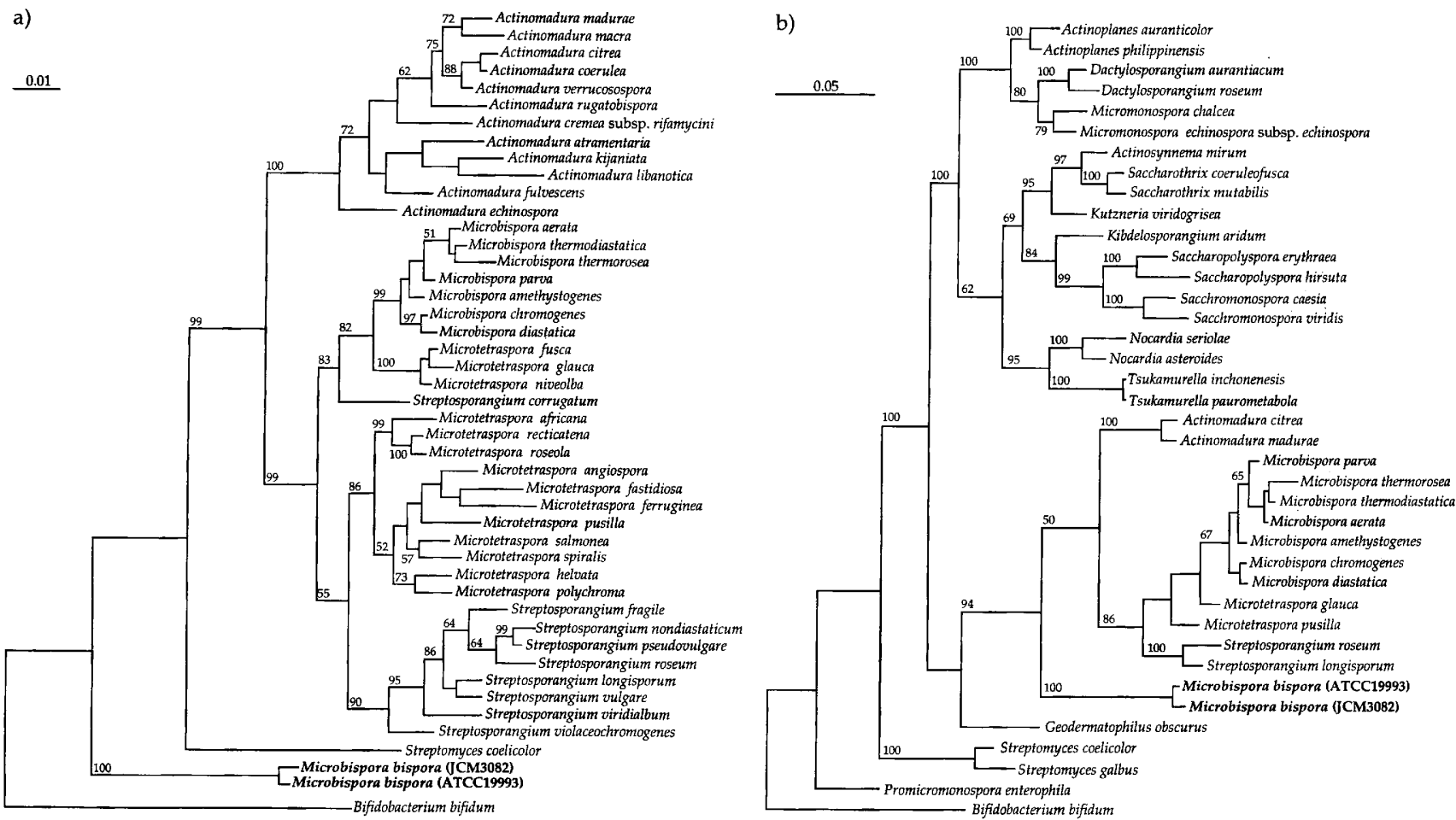

FIG. 2. Phylogenetic trees for Microbispora bispora strains with members of the family Streptosporangiaceae and Actinomadura species (a) and with 39 representative species of 19 actinomycete genera (b). The trees were generated by using a maximum-parsimony method (19). Treatment of alignment gaps either as a NEWSTATE or as MISSING had little effect on the general topologies of the trees. The numbers at the nodes are bootstrap values (based on 100 resamplings). (a) Bar $=1$ inferred substitution per 100 nucleotides. (b) Bar $=5$ inferred substitutions per 100 nucleotides. Trees with similar topologies were also generated by using the Saitou-Nei (17) neighbor-joining method contained in the Clustal $\mathrm{V}$ multiple-sequence alignment package (5) (data not shown)

DNA homology (about $16 \%$ ) of this organism and Actinomadura species to the other Microbispora strains (12). Furthermore, more than $60 \%$ of the previously reported levels of DNA homology among the 10 strains were less than $60 \%$ (12), which does not justify combining all 10 species into one taxon (6). The same concern was also raised in previous reports $(16,20)$

Description of Thermobispora gen. nov. Thermobispora (Ther.mo.bi.spo'ra. Gr. adj. thermos, hot; Gr. adj. bis, two; Gr. fem. n. spora, seed; M. L. fem. n. Thermobispora, high temperature two-spored organisms). The strains are gram-positive, aerobic, non-acid-fast, thermophilic organisms that produce substrate mycelia with hyphae which are 0.5 to $0.8 \mu \mathrm{m}$ in diameter. The aerial mycelia branch monopodially and bear longitudinal pairs of spores which are usually arranged alternately on side branches arising from the main hyphae. The smooth-surface spores are oval to spherical and nonmotile. Fragmentation of mycelia is not observed on agar or in liquid media. Neither sclerotia, sporangia, nor any other special structure is formed. The cell wall contains a major amount of meso-diaminopimelic acid, and the whole-cell hydrolysate contains madurose and galactose. MK- $9\left(\mathrm{H}_{0}\right)$ is the major menaquinone. The phospholipid pattern type is type PIV, and the phospholipids include a small amount of glucosamine-containing phospholipids. 14-Methylpentadecanoic acid is the major fatty acid. The DNA G+C content is $70 \mathrm{~mol} \%$.

Description of Thermobispora bispora (Lechevalier 1965) comb. nov. Thermobispora bispora (bi. spo'ra. Gr. adj. bis, two; Gr. fem. n. spora, seed; M. L. fem. adj. bispora, two spores) type strain ATCC 19993 grows at 50 to $65^{\circ} \mathrm{C}$ but not at $35^{\circ} \mathrm{C}$. This organism is an absolutely thermophilic actinomycete. Sub- strate and aerial mycelia are formed. Longitudinal pairs of spores are borne on the branches of the aerial mycelia. The diameters of the spores are usually 1.2 to $2.0 \mu \mathrm{m}$, but occasionally spores with a diameter of $3 \mu \mathrm{m}$ are observed in liquid culture. The aerial mycelia are white and the substrate mycelia are yellow or yellowish brown on International Streptomyces Project medium 4 and IFO328 medium. No soluble pigment is produced. Starch is not hydrolyzed. Negative for iodinin production and nitrate reduction. Inositiol and rhamnose are utilized for growth, but arabinose and glycerol are not utilized.

\section{ACKNOWLEDGMENT}

This work was supported by the Institute of Molecular and Cell Biology, National University of Singapore.

\section{REFERENCES}

1. Brosius, J., J. J. Palmer, J. P. Kennedy, and H. F. Noller. 1978. Complete nucleotide sequence of a $16 \mathrm{~S}$ ribosomal gene from Escherichia coli. Proc. Natl. Acad. Sci. USA 75:4801-4805.

2. Goodfellow, M. 1989. Maduromycetes, p. 2509-2551. In S. T. Williams, M. E. Sharpe, and J. G. Holt (ed.), Bergy's manual of systematic bacteriology, vol. 4. The Williams \& Wilkins Co., Baltimore.

3. Goodfellow, M. 1992. The family Streptosporangiaceae, p. 1116-1138. In A. Balows, H. G. Trüper, M. Dworkin, W. Harder, and K. H. Schleifer (ed.), The procaryotes. Springer-Verlag, New York.

4. Henssen, A. 1957. Beitrage zur morphologie und systematik der thermophilen actinomyceten. Arch. Mikrobiol. 26:374-414.

5. Higgines, D. G., A. J. Bleasby, and R. Fuchs. 1992. CLUSTAL V: improved software for multiple sequence alignment. Comput. Appl. Biosci. 8:189-191.

6. Johnson, J. L. 1984. Nucleic acids in bacterial classification, p. 8-11 In N. R. Krieg and J. G. Holt (ed.), Bergey's manual of systematic bacteriology, vol. 1. Williams and Wilkins, Baltimore.

7. Kroppenstedt, R. M., and M. Goodfellow. 1992. The family Thermomonosporaceae, p. 1085-1114. In A. Balows, H. G. Trüper, M. Dworkin, W. 
Harder, and K. H. Schleifer (ed.), The procaryotes. Springer-Verlag, New York.

8. Lane, D. J. 1991. 16S/23S rRNA sequencing, p. 115-175. In E. Stacketbrand and M. Goodfellow (ed.), Sequencing and hybridization techniques in bacterial systematics. John Wiley \& Sons, Chichester, England.

9. Lechevalier, H. A. 1965. Priority of the generic name Microbispora over Waksmania and Thermopolyspora. Int. Bull. Bacteriol. Nomencl. Taxon. 15: 139-142.

10. Lechevalier, M. P., and H. A. Lechevalier. 1957. A new genus of the Actinomycetales: Waksmania gen. nov. J. Gen. Microbiol. 17:104-111.

11. Maniatis, T., E. F. Fritsch, and J. Sambrook. 1982. Molecular cloning: laboratory manual. Cold Spring Harbor Laboratory, Cold Spring Harbor, N.Y.

12. Miyadoh, S., S. Amano, H. Tohyama and T. Shomura. 1990. A taxonomic review of the genus Microbispora and a proposal to transfer two species to the genus Actinomadura and to combine ten species into Microbispora rosea. J. Gen. Microbiol. 136:1905-1913.

13. Miyadoh, S. S., H. Tohyama, S. Amano, T. Shomura, and T. Niida. 1987. Microbispora viridis, a new species of Actinomycetales. Int. J. Syst. Bacteriol. 37:342-346.

14. Nonomura, H., and Y. Ohara. 1957. Distribution of actinomycetes in soil. II. Microbispora, a new genus of Streptomycetaceae. J. Ferment. Technol. 35: 307-311.
15. Nonomura, H., and Y. Ohara. 1960. Distribution of actinomycetes in soil. IV. The isolation and classification of the genus Microbispora. J. Ferment. Technol. 38:401-405.

16. Ochi, K., K. Haraguchi, and S. Miyadoh. 1993. A taxonomic review of the genus Microbispora by analysis of ribosomal protein AT-L30. Int. J. Syst. Bacteriol. 43:58-62.

17. Saitou, N., and M. Nei. 1987. The neighbor-joining method: a new method for reconstructing phylogenetic trees. Mol. Biol. Evol. 4:406-425.

18. Stackebrandt, E., and C. R. Woese. 1991. Towards a phylogeny of the actinomycetes and related organisms. Curr. Microbiol. 5:197-202.

19. Swofford, D. L., and D. P. Begle. 1993. Phylogenetic analysis using parsimony, version 3.1, user's manual. Laboratory of Molecular Systematics, Smithsonian Institution, Champaign, Ill.

20. Wang, Y., Z. S. Zhang, and J. S. Ruan. 1996. Phylogenetic analysis reveals new relationships among members of the genera Microtetraspora and Microbispora. Int. J. Syst. Bacteriol. 46:658-663.

21. Woese, C. R. 1987. Bacterial evolution. Microbiol. Rev. 51:221-271.

22. Woese, C. R., O. Kandler, and M. L. Wheelis. 1990 . Towards a natural system of organisms: proposal for the domains Archaea, Bacteria and Eucarya. Proc. Natl. Acad. Sci. USA 87:4576-4579.

23. Woese, C. R., E. Stackebrandt, T. J. Macke, and G. E. Fox. 1985. A phylogenetic definition of the major eubacterial taxa. Syst. Appl. Microbiol. 6:143151 